\title{
Flavobacterium hibernum sp. nov., a lactose- utilizing bacterium from a freshwater Antarctic lake
}

1 Antarctic.CRC, University of Tasmania, Box 252C, Hobart 7001, Australia

2 CSIRO - Division of Marine Research, GPO Box 1538, Hobart 7000, Australia

3 CSIRO Land and Water, Underwood Ave, Floreat Park WA 6014, Australia

4 Australian Antarctic Division, Channel Highway, Kingston 7050, Australia

\author{
S. A. McCammon, ${ }^{1}$ B. H. Innes, ${ }^{2}$ J. P. Bowman, ${ }^{1}$ P. D. Franzmann, ${ }^{3}$ \\ S. J. Dobson, ${ }^{1}$ P. E. Holloway, ${ }^{1}$ J. H. Skerratt, ${ }^{1}$ P. D. Nichols ${ }^{1,2}$ \\ and L. M. Rankin ${ }^{4} \dagger$
}

\author{
Author for correspondence: P. D. Franzmann. Tel: +61893336306. Fax: +61893878211. \\ e-mail: Peter.Franzmann $(\alpha$ per.clw.csiro.au
}

\begin{abstract}
Four freshwater Antarctic lakes were examined for the presence of $\beta$ galactosidase-producing bacteria using mineral medium enrichments and lactose. Enrichments from only one of the lakes produced growth and two strains were isolated that were very similar in phenotype and fatty acid profile, and shared considerable homology in their DNA (DNA-DNA hybridization $=93 \pm 7 \%$ ). The strains were psychrotrophic with theoretical $T_{\max }$ $T_{\min }$ and $T_{\text {opt }}$ of $30-31,-7^{\circ}$ and $26^{\circ} \mathrm{C}$, respectively. The $\beta$-galactosidase in cell extracts had an optimal activity at $39^{\circ} \mathrm{C}$. The strains were Gram-negative rods, showed gliding motility, contained branched and hydroxy fatty acids, and menaquinone 6 as the major respiratory quinone. The strains did not form microcysts and utilized lactose while using ammonium ions as a source of nitrogen, and a range of other sugars. The $G+C$ content of the DNA was $34 \mathrm{~mol} \%$. Phylogenetic analysis of one of the strains, by comparison of 165 rDNA sequences, showed that it was most similar, but not identical to, Flavobacterium columnare and '[Sporocytophaga] cauliformis'. Both species could be differentiated phenotypically from the Antarctic isolates. DNA-DNA hybridization of the Antarctic isolate with six different members of the Flavobacterium 165 rDNA cluster showed no strain with greater than $18 \%$ relatedness. The nearest type species to the Antarctic isolate in the phylogenetic analysis was Flavobacterium aquatile. The name Flavobacterium hibernum is proposed for the Antarctic strains, and the type strain is ATCC $51468^{\top}$ ( = ACAM 376 ${ }^{\top}$ ).
\end{abstract}

Keywords: Flavobacterium hibernum, psychrotroph, $\beta$-galactosidase, Antarctica

\section{INTRODUCTION}

Many humans are intolerant to lactose in their diet and as a result are unable to consume unfermented dairy products without considerable discomfort. One technological approach to solving this problem is to use $\beta$ galactosidase in the processing of dairy foods. However, the optimal temperatures for hydrolysis of lactose by $\beta$-galactosidases range between 30 and $40{ }^{\circ} \mathrm{C}$, which

†Present address: PO Box 302, Parap NT 0804, Australia.

Abbreviation: RDP, ribosomal database project.

The GenBank accession number for the sequence reported in this paper is L39067. is also the ideal temperature range for the growth of mesophiles that contaminate and spoil dairy products (Gounot, 1991). Hydrolysis of lactose at low temperatures may be a viable option if a psychrophile can be isolated that produces an efficient low-temperature $\beta$-galactosidase (Gounot, 1991).

As part of an ongoing study on the microbial diversity of Antarctic ecosystems, and due to the possible benefits arising from the isolation of psychrophilic $\beta$ galactosidase-producing strains, we targeted lactoseutilizing strains from a number of freshwater Antarctic lakes for enrichment and isolation. A taxonomic study of the isolates was undertaken and the work is herein described. 


\section{METHODS}

Bacterial strains. Strain designation is by culture collection number. The culture collections referred to are as follows: ACAM, Australian Collection of Antarctic Microorganisms, University of Tasmania, Australia; DSMZ, Deutsche Sammlung von Mikroorganismen und Zellkulturen, Braunschweig, Germany; ATCC, American Type Culture Collection, Manassas, VA, USA; NCIMB, National Collection of Industrial and Marine Bacteria, Aberdeen, UK; IFO, Institute for Fermentation, Osaka, Japan; IAM, Institute of Applied Microbiology, University of Tokyo, Japan; NCTC, National Collection of Type Cultures, Public Health Laboratory, London, UK.

Isolation of bacterial strains. Four freshwater Antarctic lakes [conductivity $\left(\mu \mathrm{S} \mathrm{cm}^{-1}\right)$ and $\mathrm{pH}$ given in parentheses after each namel: Druzhby Lake $(29,7 \cdot 2)$, Crooked Lake $(26,7 \cdot 1)$, Pauk Lake $(118,7 \cdot 0)$ and Lichen Lake $(73,7 \cdot 3)$, were sampled for lactose-utilizing bacteria. Each lake was sampled twice, at the same hour from sample points within $10 \mathrm{~m}$ of each other. From each sample, an enrichment for lactose-utilizing bacteria was prepared by adding $1 \mathrm{ml}$ surface water to $9 \mathrm{ml}$ lactose broth that contained (per 1 distilled water): $\mathrm{K}_{2} \mathrm{HPO}_{4}, 0.5 \mathrm{~g} ;\left(\mathrm{NH}_{4}\right)_{2} \mathrm{SO}_{4}, 0.5 \mathrm{~g} ; \mathrm{NaCl}$, $0.05 \mathrm{~g}$; lactose (filter-sterilized), $5.0 \mathrm{~g}$. The enrichments were incubated at $2{ }^{\circ} \mathrm{C}$ for 1 month. Those enrichments showing turbidity were streaked onto lactose medium (solidified with $1.5 \%, \mathrm{w} / \mathrm{v}$, agar) and incubated aerobically at $2{ }^{\circ} \mathrm{C}$ for $20 \mathrm{~d}$. A pure culture was prepared from each plate by replating isolated colonies through three successive transfers. Strains were deposited, originally under the name 'Flavobacterium ameridies', in the Australian Collection of Antarctic Microorganisms as ACAM 376 and ACAM 377. ACAM 376 was also deposited in the American Type Culture Collection as ATCC $51468^{\mathrm{T}}$. Subsequently, the strains were routinely grown on lactose medium that was supplemented with $0.1 \%$ yeast extract and $0.05 \% \mathrm{NaCl}$, solidified with $1.5 \%(\mathrm{w} / \mathrm{v})$ agar; this was defined as 'maintenance medium'.

Determination of optimal growth temperature. Maintenance medium without agar was dispensed in $10 \mathrm{ml}$ amounts in Ltubes (supplied with temperature-gradient incubator) and placed in a temperature-gradient incubator (Toyo) set from $0-35^{\circ} \mathrm{C}$, with 30 tubes spanning that temperature range. Each tube was inoculated with $1 \mathrm{ml}$ relevant test strain and growth curves were prepared for each strain at each temperature, measuring growth by increase in $\mathrm{OD}_{550}$. Growth data were fitted to the Ratkowsky temperature growth model (Ratkowsky et al., 1983) using OptiCurve 2.0 (Softhansa).

Temperature characteristics of $\boldsymbol{\beta}$-galactosidase activity. Cells were grown in maintenance media at $25^{\circ} \mathrm{C}$ for $48 \mathrm{~h}$, collected by centrifugation and resuspended in phosphate buffer $(0 \cdot 1 \mathrm{M}, \mathrm{pH} 7 \cdot 0)$. Cells were lysed in a French pressure cell and the suspension of lysed cells was used as a source of crude enzyme. $\beta$-Galactosidase was assayed using the method of Miller (1972). To determine the optimum temperature for the enzyme, an array of tubes containing the assay mixture was temperature equilibrated in the temperature-gradient incubator (range $16-48^{\circ} \mathrm{C}$ ). In all tubes, the reaction was started by the addition of $2.6 \mathrm{mM}$ ONPG and stopped by the addition of $1 \mathrm{M} \mathrm{Na}_{2} \mathrm{CO}_{3}$ after $28 \mathrm{~min}$. The rate of reaction at each temperature was determined and fitted to the Arrhenius equation model.

To obtain an estimate of the theoretical minimum temperature for enzyme activity, the experiment was repeated at a temperature range between 3 and $19^{\circ} \mathrm{C}$. Data were fitted to the Ratkowsky model (Ratkowsky et al., 1983).

Morphological and physiological tests. Colony morphology was determined on maintenance medium after $5 \mathrm{~d}$ growth at $25^{\circ} \mathrm{C}$. Cells grown for $48 \mathrm{~h}$ at $25^{\circ} \mathrm{C}$ on maintenance medium were tested for their reaction to the Gram stain (Skerman, 1967), and for catalase, oxidase and nitrate reduction (Smibert \& Krieg, 1981). The ability to grow anaerobically was tested by inoculating boiled and degassed maintenance medium under a nitrogen headspace under butyl rubber in Hungate tubes. The ability to utilize a range of carbon sources was tested using a Biolog GN Microplate after growth of strains on Tryptic Soy Agar (Oxoid) at $25^{\circ} \mathrm{C}$. Plates were incubated at $25^{\circ} \mathrm{C}$ and readings taken at 4 and $24 \mathrm{~h}$. Otherwise the manufacturer's instructions were followed. Reactions in API 20NE and API 20E were tested as described by the manufacturer, except that the tests were incubated at $25^{\circ} \mathrm{C}$ for $48 \mathrm{~h}$. Growth on seawater medium, flexirubin production, egg yolk precipitation, production of diffusible pigment on tyrosine agar, and degradation of casein, Tween 80 , starch, DNA, L-tyrosine, chitin, agar, alginate, urate and xanthine were tested as described by Bowman et al. (1996). CM-cellulose hydrolysis was tested by overlaying nutrient agar with a thin layer of $0.5 \% \mathrm{CM}$ cellulose in tap-water agar and examining after two weeks for zones of hydrolysis. Pectin hydrolysis was tested by the method of Hildebrand (1971). Congo red adsorption was tested by the method of McCurdy (1969). Alginate hydrolysis was tested by the method of West \& Colwell (1984). To test bacteriolytic activity, Escherichia coli ACM 1803 was grown in nutrient broth (Oxoid) at $37^{\circ} \mathrm{C}$ for $24 \mathrm{~h}$. Cells were collected by centrifugation and washed in $1.0 \mathrm{~g} \mathrm{~K}_{2} \mathrm{HPO}_{4} \mathrm{I}^{-1}$ in distilled water. The cells were resuspended in phosphate solution and steamed at $100^{\circ} \mathrm{C}$ for $10 \mathrm{~min}$. Agar plates of the following composition (per l): $\mathrm{K}_{2} \mathrm{HPO}_{4}, 0.5 \mathrm{~g}$; $\mathrm{MgSO}_{4} .7 \mathrm{H}_{2} \mathrm{O}, 0.5 \mathrm{~g} ; \mathrm{NH}_{4} \mathrm{Cl}, 0.5 \mathrm{~g} ; \mathrm{NaCl}, 0.05 \mathrm{~g}$; agar, $15.0 \mathrm{~g}$, were prepared. Agar plates were overlaid with a $1 \mathrm{~mm}$ layer of the same agar containing the steamed cells of $E$. coli that had been added at $50^{\circ} \mathrm{C}$ so as to give slight turbidity to the overlay. These plates were centrally inoculated and incubated for $7 \mathrm{~d}$ at $25^{\circ} \mathrm{C}$.

Motility was examined by hanging drop (Skerman, 1967). Slides were overlaid with a thin film of the nutrient-poor agar used as underlay in the test for bacteriolytic activity, except that Noble Agar (Difco) was used as the gelling agent. Ability to glide was tested by examination of cells between a coverglass and the freshly coated slides using a $100 \times$ oilimmersion phase-contrast objective.

Chemotaxonomic tests. Cells were grown in 11 maintenance medium, collected by centrifugation, washed in $1.0 \mathrm{~g}$ $\mathrm{K}_{2} \mathrm{HPO}_{4} \mathrm{l}^{-1}$ in distilled water and freeze-dried. Respiratory lipoquinones were extracted from $0 \cdot 1 \mathrm{~g}$ cells (dry weight) by the method of Athalye et al. (1984) and the major components were identified by HPLC (Tamaoka et al., 1983). Methyl esters of whole-cell fatty acids (FAMEs) were extracted from stationary phase cells by the method of Moss et al. (1988). The profile of FAMEs was determined by $\mathrm{GC} /$ flame-ionization detection and GC/MS as described by Skerratt et al. (1991).

DNA composition. DNA was extracted from cells by the phenol extraction method of Mesbah et al. (1989) and the $\mathrm{G}+\mathrm{C}$ content was determined by HPLC (Mesbah et al., 1989) using bacteriophage lambda DNA (Sigma) as the standard.

16S rRNA gene sequence analysis. Extracted DNA was further purified by a cetyltrimethylammonium bromide 
treatmenı (Murray \& Thompson, 1980). PCR was used to amplify $95 \%$ of the $16 \mathrm{~S}$ rRNA gene and the product was directly sequenced by the methods described by Dobson et al. (1993) The sequence of 1461 bases, between bases 27 and 1517 ( $E$. coli numbering), was aligned with prealigned sequences of rRNA genes and rDNA available from the Ribosomal Database Project (RDP) Release 6.1 (Larsen et al., 1993). The sequences used were obtained from the following organisms (with GenBank sequence accession no. in parentheses unless otherwise stated): Flavobacterium hibernum ACAM 376 (L39067); Flavobacterium hydatis ATCC $29551^{\mathrm{T}}$ (M58764), F. hydatis IAM 12365 (D12656), Flavobacterium succinicans IFO 14905 (D12673), $F$. succinicans DSM 4002 (RDP sequence F.succinic), Flavobacterium psychrophilium DSM 3660" (D12670), "[Sporocytophaga] cauliformis' DSM 3657 (M93151), Flavobacterium johnsoniae DSM 425 (M59053), Flavobacterium columnar' ATCC 43622 (M58781), Cytophaga sp. L-43-1-N (D12675), Flavobacterium pectinovorum DSM $6368^{\mathrm{tg}}$ (D12669), Flavobacterium flevense ATCC 27944 (M58767), F. flevense' IFO 14960 (D12662), Flavobacterium aurantiacus ATCC 17061 ${ }^{\mathrm{T}}$ (M59051), F. johnsoniae IFO 14942 (D12664), Flavobacterium saccharophilum ATCC $49530^{\mathrm{T}}$ (RDP sequence F.saccharo), $F$. saccharophilum DSM $1811^{\mathrm{T}}$ (D12671). Flavobacterium columnare ATCC 23463 (D12659). Flavobacterium aquatile ATCC 11947' (M62797), Weeksella virosa NCTC 11634 (M93152). The aligned 16S rRNA gene sequences were compared, between bases 27 and 1517 (E. coli numbering), using PAup version 3.1 (Swofford, 1990) to determine dissimilarity between the sequences. All sequences showing a dissimilarity of $>3.5 \%$ were excluded from further analyses except for the sequences for $F$. aquatile, the nearest type species, and $W$. virosa, which would be used as the outgroup in the phylogenetic analyses. The duplicated sequences for $F$. hydatis and $F$. saccharophilum, D12656 and D12671, were also deleted from further analyses. Dissimilarity between the remaining sequences was again determined using Paup version 3.1. A phylogenetic tree was prepared using this restricted set of sequences and the program tastDNAml of the RDP (Larsen et al., 1993) and the sequence of $W$. virosa as the outgroup.

DNA-DNA reassociation. The spectrophotometric renaturation rate kinetic procedure as adapted by Huss et al. (1983) was used to determine DNA-DNA reassociation values between genomic DNA of different strains. In this method, homology is calculated from DNA renaturation rates of homologous and mixture DNA. Genomic DNA was sheared to a mean size of $1 \mathrm{~kb}$ using sonication, dialysed overnight at $4{ }^{\circ} \mathrm{C}$ in $3 \times \mathrm{SSC}$ buffer $(0.45 \mathrm{M} \mathrm{NaCl}, 0.045 \mathrm{M}$ sodium citrate, $\mathrm{pH} 7 \cdot 0$ ), and adjusted in concentration to approximately $60 \mathrm{~g} \mathrm{ml}^{-1}$. Following denaturation of the DNA samples, hybridization was performed at the optimal temperature for renaturation $\left(T_{\mathrm{OR}}\right)$ which was $25^{\circ} \mathrm{C}$ below the DNA melting temperature and was calculated from the following equation: $T_{\mathrm{OR}}{ }^{\circ} \mathrm{C}=48 \cdot 5+(0 \cdot 41 \times \mathrm{mol} \% \mathrm{G}+\mathrm{C})$. The decline in absorbance over a $40 \mathrm{~min}$ interval of DNA mixtures and control DNA samples were used to calculate DNA hybridization values using the following equation (Huss et al., 1983): \% DNA hybridization = $(4 A B-A-B / 2 \sqrt{ }(A \times B)) \times 100 \%$, in which $A$ and $B$ represent the change in absorbance for the two DNA samples being compared and $A B$ represents the change in absorbance for equimolar mixtures of $A$ and $B$. DNA hybridization values equal to or below $25 \%$ are considered to represent background hybridization and are not considered significant.

\section{RESULTS}

\section{Bacterial strains}

Of the lakes samples used to inoculate the enrichments of mineral medium containing lactose, only those from Crooked Lake became visibly turbid after incubation at $2{ }^{\circ} \mathrm{C}$ for 1 month. Both enrichments contained cells of uniform morphology which, when plated on solid medium, produced colonies of a single type. A single strain was isolated from each enrichment and deposited in the Australian Collection of Antarctic Microorganisms as ACAM 376 ${ }^{\mathrm{T}}$ and ACAM 377.

\section{Phenotypc attributes}

Both strains were identical in morphology and a photomicrograph of ACAM $376^{\mathrm{T}}$ is shown in Fig. 1 . Cells were Gram-negative rods, $0.7 \times 1.8-13 \mu \mathrm{m}$ that exhibited gliding motility on fresh, nutrient-poor medium. Colonies on media containing $0.5 \%$ lactose and $0.1 \%$ yeast extract were discrete, opaque, shiny, smooth and yellow, mucoid when grown at $25^{\circ} \mathrm{C}$ but gelatinous when grown at $4{ }^{\circ} \mathrm{C}$. Cells grown at $4{ }^{\circ} \mathrm{C}$ possessed a thick capsule. On the nutrient-poor medium, colonies were translucent and spread over the agar surface. Both strains lysed cells of $E$. coli that had been boiled and embedded in agar. Neither strain grew anaerobically. Both strains were catalase-positive, oxidase-negative, and contained menaquinone 6 as their major (>94\%) respiratory lipoquinone. Fatty acid profiles of ACAM $376^{\mathrm{T}}$ and ACAM 377 were very similar in types and relative proportions of component fatty acids. The complete listing of fatty acid composition of the Antarctic strains with values expressed as percentage of total fatty acids is given in parentheses after each fatty acid type (for ACAM $376^{\mathrm{T}}$ and ACAM 377 , respectively), is as follows: i13:0 $(0 \cdot 1,0 \cdot 1)$, a 13:0

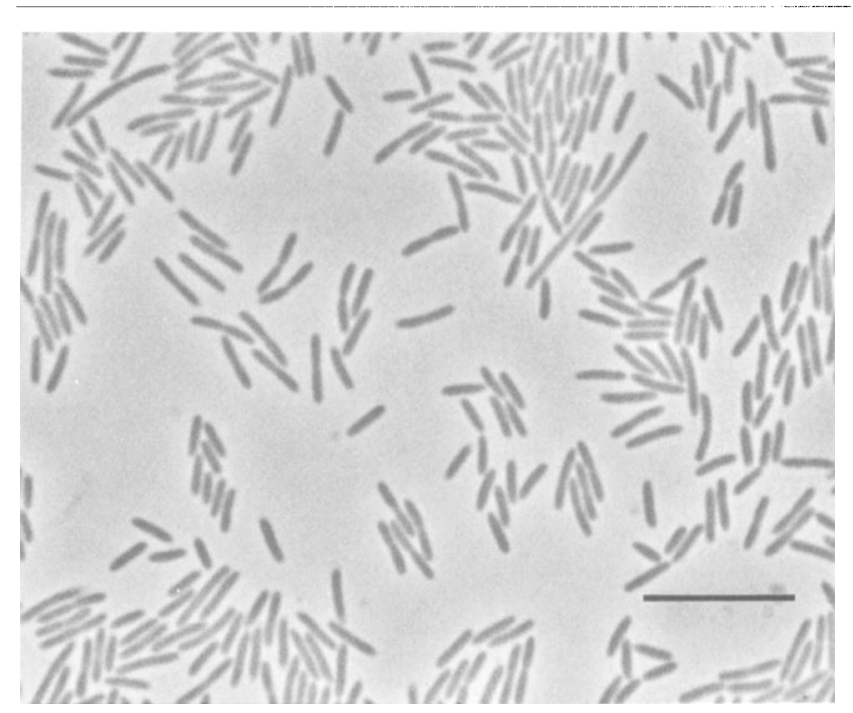

Fig. 1. Photomicrograph of Flavobacterium hibernum ACAM $376^{\top}$ grown on nutrient-poor medium at $20^{\circ} \mathrm{C}$ for $24 \mathrm{~h}$. Bar, $10 \mu \mathrm{m}$. 


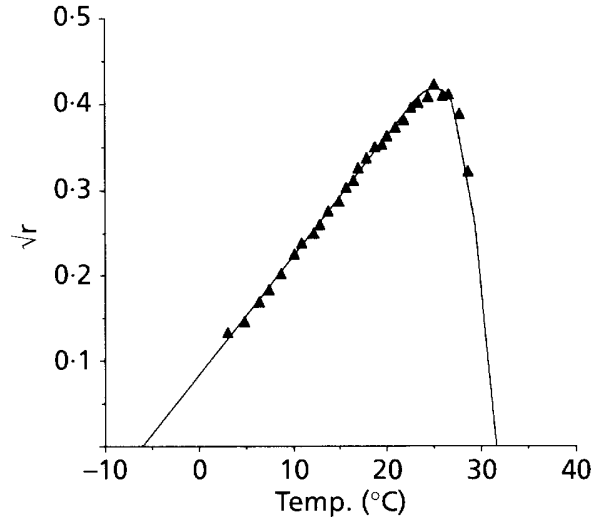

Fig. 2. Fitted Ratkowsky model of growth versus temperature data for Flavobacterium hibernum. $\mathrm{r}$ is the square-root of the reciprocal of the time taken to increase the initial $O_{550}$ by 0.3 units.

$(0 \cdot 1,0 \cdot 1), \mathrm{i} 14: 0(0 \cdot 1,0 \cdot 1), 14: 1(0 \cdot 0,0 \cdot 1), 14: 0(0 \cdot 5,0 \cdot 6)$, i15: $1 \omega 10 c(5 \cdot 2,5 \cdot 2)$, a $15: 1 \omega 10 c(0 \cdot 7,0 \cdot 7)$, i15:0 $(18 \cdot 6$, $20 \cdot 2)$, a $15: 0(7 \cdot 5,8 \cdot 1), 15: 1 \omega 6 c(4 \cdot 0,4 \cdot 1), 15: 0(7 \cdot 8$, $7 \cdot 4)$, i $16: 1 \omega 6 c(1 \cdot 5,1 \cdot 6)$, i16:0 $(1 \cdot 1,1 \cdot 3), 16: 1 \omega 9 c(1 \cdot 0$, $0 \cdot 8), 16: 1 \omega 7 c(17 \cdot 7,19 \cdot 7), 16: 1 \omega 5 c(0 \cdot 5,0 \cdot 6), 16: 0(2 \cdot 9$, $3 \cdot 2)$, i1 $17: 1 \omega 7 c(2 \cdot 9,2 \cdot 8)$, a $17: 1 \omega 5 c(1 \cdot 7,1 \cdot 9)$, i $17: 0(0 \cdot 2$, $0 \cdot 2)$, a $17: 0(1 \cdot 2,1 \cdot 2), 3-\mathrm{OH} 13: 0(0 \cdot 1,0 \cdot 1), 3-\mathrm{OH} 14: 0$ $(0 \cdot 8,0 \cdot 9), 3$-OHi15:0 (11.0, 10·1), 3-OHa 15:0 (1.4, 1.4), 3-OH15:0 (0.6, 0.4), 3-OHi16:0 (2.9, 1.5), 3-OH16:0 $(2 \cdot 2,1 \cdot 8), 3$-OHi17:0 $(3 \cdot 9,2 \cdot 8), 3$-OHa 17:0 (1.5, 0.9). The strains contained flexirubins, did not adsorb congo red, did not produce diffusible pigments on tyrosine agar and did not form a precipitate in egg yolk agar. Nitrate was reduced to nitrite in the API tests.

Both strains displayed similar growth responses to temperature, and the Ratkowsky model, fitted to growth versus temperature data for ACAM $376^{\mathrm{T}}$, is given in Fig. 2. Both strains had optimal growth temperatures of $26^{\circ} \mathrm{C}$, with theoretical minimum growth temperatures of $-7{ }^{\circ} \mathrm{C}$. Maximal growth temperatures were $30^{\circ} \mathrm{C}$ for ACAM $376^{\mathrm{T}}$ and $31{ }^{\circ} \mathrm{C}$ for ACAM 377. Both strains grew on $0-2 \% \mathrm{NaCl}$, but not on $5 \% \mathrm{NaCl}$ or on seawater agar. The strains grew on trypticase soy agar. Both strains degraded casein, Tween 80 , starch, DNA and L-tyrosine, but not chitin, agar, alginate, CM-cellulose, pectin, urate, or xanthine.

The strains showed $97 \%$ similarity in the Biolog test system and gave identical results in the API test systems. In the Biolog system, both strains utilized $\alpha$ cyclodextrin, dextrin, glycogen, Tween 40 , Tween 80 , $N$-acetyl-D-galactosamine, $N$-acetyl-D-glucosamine, Larabinose, cellobiose, D-fructose, L-fructose, D-galactose, gentiobiose, D-glucose, D-lactose, lactulose, maltose, D-mannitol, D-mannose, D-melibiose, methyl $\beta$-Dglucoside, D-psicose, L-rhamnose, D-sorbitol, sucrose, D-trehalose, methyl pyruvate, mono-methyl succinate, acetic acid, D-gluconic acid lactone, D-galacturonic acid, D-galactonic acid, D-glucuronic acid, $\alpha$-keto butyric acid, DL-lactic acid, propionic acid, succinic

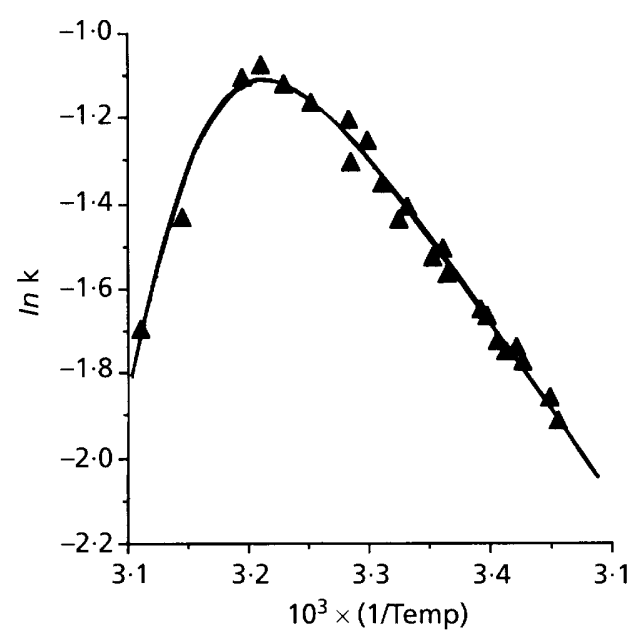

Fig. 3. Fitted Arrhenius plot of $\beta$-galactosidase activity versus temperature for $\beta$-galactosidase activity from Flavobacterium hibernum. In $\mathrm{k}$ is the natural $\log$ of the absorbance of reaction product formed after incubation for $28 \mathrm{~min}$. $1 /$ Temp. is the reciprocal of the absolute temperature.

acid, bromo succinic acid, alaninamide, D-alanine, Lalanine, L-alanyl-glycine, L-asparagine, L-aspartic acid, L-glutamic acid, glycyl-L-glutamic acid, L-ornithine, L-proline, D-serine, L-serine, L-threonine, inosine, uridine, thymidine, glycerol, $\mathrm{D}, \mathrm{L}-\alpha-$-glycerol phosphate, glucose-1-phosphate and glucose-6-phosphate. Neither strain utilized adonitol, D-arabitol, ierythritol, m-inositol, D-raffinose, turanose, xylitol, cis-aconitic acid, citric acid, D-glucosaminic acid, $\alpha$ hydroxybutyric acid, $\beta$-hydroxybutyric acid, $\gamma$ hydroxybutyric acid, p-hydroxyphenylacetic acid, itaconic acid, $\alpha$-keto glutaric acid, $\alpha$-keto valeric acid, malonic acid, quinic acid, sebacic acid, succinamic acid, glycyl-L-aspartic acid, L-histidine, hydroxy Lproline, L-leucine, L-phenylalanine, L-pyroglutamic acid, D,L-carnitine, $\gamma$-amino butyric acid, urocanic acid, phenyl ethylamine, putrescine, 2-amine ethanol, 2,3-butanediol. Unlike ACAM 377, ACAM $376^{\mathrm{T}}$ utilized formic acid, glucuronamide and saccharic acid.

In the API $20 \mathrm{E}$ test, both strains were positive for $\beta$ galactosidase, gelatin hydrolysis, nitrate reduction and acid from glucose, rhamnose, saccharose and arabinose. The strains were negative for the following: arginine, lysine and ornithine decarboxylase, citrate utilization, $\mathrm{H}_{2} \mathrm{~S}$ production, indole production, Vogues-Proskauer test, tryptophan deaminase and acid from mannose, inositol, sorbitol, melibiose or amylose. In the API 20NE test, both strains hydrolysed aesculin and utilized arabinose, mannose, $\mathrm{N}$-acetyl glucosamine and maltose but not mannitol, gluconate, caprate, adipate, malate, citrate, phenylacetate. Both strains were negative for arginine dihydrolase and urease.

The relationship of the activity of $\beta$-galactosidase from ACAM $376^{\mathrm{T}}$ with temperature is shown in the Arrhenius plot in Fig. 3. The optimum temperature for 


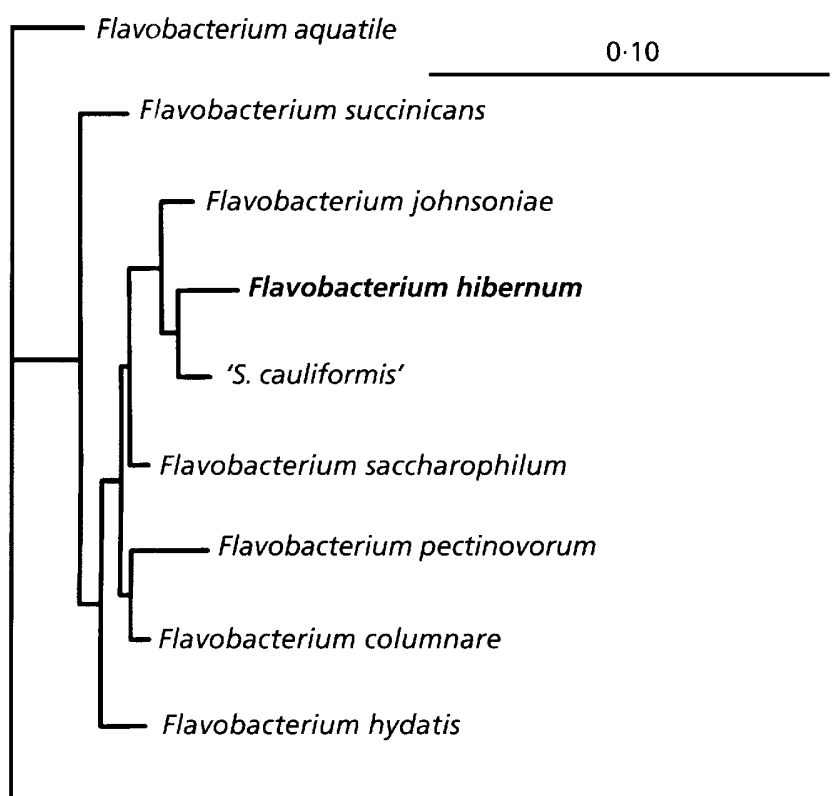

Weeksella virosa

Fig. 4. Phylogenetic relationships of Flavobacterium hibernum with other selected closely related strains, based on analysis of approximately 1461 base segments of 16S rRNA and 16S rDNA with analysis using the program fastDNAml and Weeksella virosa as the outgroup. The bar represents 10 base substitutions per 100 bases.

activity of the $\beta$-galactosidase was $38.6^{\circ} \mathrm{C}$. The theoretical minimum temperature for enzyme activity was $-34{ }^{\circ} \mathrm{C}$.

\section{Molecular and phylogenetic characteristics}

ACAM $376^{\mathrm{T}}$ contained DNA of $34 \cdot 2 \pm 0.7 \mathrm{~mol} \%$ $\mathrm{G}+\mathrm{C}(\mathrm{n}=7)$. About $95 \%$ of the $16 \mathrm{~S}$ rDNA was sequenced, and the sequence has been deposited in GenBank under accession number L39067, originally under the name 'Flavobacterium ameridies'. The dissimilarities $(\%)$ in $16 \mathrm{~S}$ rDNA sequences of strain ACAM $376^{\mathrm{T}}$ with other closely related members of the
Flavobacterium group and outgroups were ' $[S$.] cauliformis' DSM $3657,0 \cdot 022 ; F$. columnare ATCC $43622,0 \cdot 022 ; F$. johnsoniae DSM 425, 0.024; F. hydatis NCIMB $2215^{\mathrm{T}}, 0 \cdot 026 ; F$. hydatis IAM $12365,0 \cdot 026 ; F$. saccharophilum ATCC $49530^{\mathrm{T}}, 0 \cdot 027 ; F$. pectinovorum DSM $6368^{\mathrm{T}}, 0 \cdot 034 ; F$. succinicans IFO 14905, 0.034; Cytophaga sp. L-43-1-N, 0.039; $F$. flevense ATCC $27944^{\mathrm{T}}, 0 \cdot 041 ; F$. psychrophilium DSM $3660^{\mathrm{T}}, 0 \cdot 042 ; F$. aurantiacus ATCC $23107^{\mathrm{T}}, 0 \cdot 047 ; F$. Alevense IFO $14960,0 \cdot 049 ; F$. johnsoniae ATCC $17061^{\mathrm{T}}, 0 \cdot 049 ; F$. aquatile ATCC $11947^{\mathrm{T}}, 0.051 ; F$. johnsoniae IFO $14942,0 \cdot 056 ; F$. columnare ATCC $23463^{\mathrm{T}}, 0 \cdot 083 ; W$. virosa NCTC $11634^{\mathrm{T}}, 0 \cdot 145$. A phylogenetic tree showing the phylogenetic placement of strain ACM $376^{\mathrm{T}}$, Flavobacterium hibernum, is given in Fig. 4.

ACAM 377 showed $93 \pm 7 \%$ DNA-DNA hybridization with ACAM $376^{\mathrm{T}}$. ACAM $376^{\mathrm{T}}$ showed low DNA-DNA hybridization with a range of other strains of the genus Flavobacterium and with '[S.] cauliformis' (Table 1).

\section{DISCUSSION}

\section{Taxonomic placement on polyphasic criteria}

Strains ACAM $376^{\mathrm{T}}$ and ACAM 377 , which were very similar in phenotypic characteristics and gave a DNADNA hybridization value of $93 \pm 7 \%$, possessed an obligately aerobic metabolism, menaquinone 6 as the major respiratory lipoquinone, negative Gram reaction, an abundance of branched and hydroxy fatty acids in their fatty acid profiles and the ability to translocate by gliding, all of which are typical of members of the family Flavobacteriaceae. The group has undergone extensive taxonomic revision largely using phylogenetic data (Gherna \& Woese, 1993; Vandamme et al., 1994; Bernardet et al., 1996).

Phylogenetic analysis of ACAM $376^{\mathrm{T}}$ (Fig. 4) showed that the strain falls within the 'cytophaga' group in the sense of Gherna and Woese (1993) which was redefined as the genus Flavobacterium by Bernardet et al. (1996) The group contained the type species of the genus Flavobacterium, $F$. aquatile. ACAM $376^{\mathrm{T}}$ clustered

Table 1. Percentage DNA-DNA hybridization of the type strain of the proposed species Flavobacterium hibernum with another representative of that species and phylogenetically closely related strains

The values given are based on 3-5 replicates (standard deviations are in parentheses).

\begin{tabular}{|lc|}
\hline Strain & F. hibernum ACAM 376 $^{\mathrm{T}}$ \\
\hline F. hibernum ACAM 377 & $93( \pm 7)$ \\
F. aurantiacus ACAM $582^{\mathrm{T}}\left(=\right.$ ATCC $\left.23170^{\mathrm{T}}\right)$ & $18( \pm 5)$ \\
F. flevens' ACAM 579 $\left(=\right.$ ATCC $\left.29530^{\mathrm{T}}\right)$ & $15( \pm 6)$ \\
F. hydatis NCIMB 2215 & $12( \pm 8)$ \\
F. johnsoniae ACAM 583 (= DSM 425) & $9( \pm 3)$ \\
F. saccharophilum ACAM 581 $(=$ ATCC 27944 $)$ & $16( \pm 11)$ \\
'[S.] cauliformis' ACAM 580 (= DSM 3657) & $6( \pm 3)$ \\
\hline
\end{tabular}


Table 2. Phenotypic comparisons that differentiate closely related existing species of the genus Flavobacterium (Bernardet et al., 1996) from the proposed species Flavobacterium hibernum

Symbols: - , all strains negative; + , all strains positive; $(+)$, weakly positive; $v$, variable result either among strains or between studies; $\mathrm{U}$, data unavailable. The species are invariant for the following attributes: growth on seawater media $(-)$, motility by gliding $(+)$, flexirubin-type pigment production $(+)$, gelatin degradation $(+)$, casein degradation $(+)$.

\begin{tabular}{|c|c|c|c|c|c|}
\hline Characteristic & F. hibernum & F. hydatis & F. saccharophilum & F. johnsoniae & F. columnare \\
\hline Colony morphology on rich media & $\begin{array}{l}\text { Low } \\
\text { convex } \\
\text { round }\end{array}$ & $\begin{array}{c}\text { Flat, } \\
\text { spreading }\end{array}$ & $\begin{array}{c}\text { Flat, } \\
\text { spreading }\end{array}$ & $\begin{array}{c}\text { Flat, } \\
\text { spreading }\end{array}$ & $\begin{array}{l}\text { Flat, } \\
\text { rhizoid }\end{array}$ \\
\hline Congo red adsorption & - & - & - & $\mathrm{V}$ & + \\
\hline Growth on nutrient agar & + & + & + & + & - \\
\hline Growth on Trypticase soy agar & + & + & + & + & - \\
\hline Glucose used as sole carbon and energy source & + & + & + & + & - \\
\hline Acid produced aerobically from glucose & + & + & + & + & - \\
\hline \multicolumn{6}{|l|}{ Degradation of: } \\
\hline Starch & + & + & + & + & - \\
\hline CM-cellulose & - & $\mathrm{v}$ & + & + & - \\
\hline Agar & - & - & + & - & - \\
\hline Alginate & - & - & $\mathrm{U}$ & + & $\mathrm{U}$ \\
\hline Pectin & - & + & + & + & $\mathrm{U}$ \\
\hline Chitin & - & $(+)$ & - & + & - \\
\hline Aesculin & + & + & + & + & - \\
\hline DNA & + & + & - & + & + \\
\hline Tyrosine & + & + & + & + & - \\
\hline Brown diffusible pigment on tyrosine agar & - & - & - & $\mathrm{v}$ & $\mathrm{v}$ \\
\hline Precipitate on egg yolk agar & - & - & - & - & + \\
\hline$\beta$-Galactosidase activity & + & + & + & + & - \\
\hline $\mathrm{H}_{2} \mathrm{~S}$ production & - & - & + & - & + \\
\hline Production of cytochrome oxidase & - & $\mathrm{v}$ & - & + & + \\
\hline Nitrate reduction & + & + & + & $\mathrm{v}$ & $\mathrm{V}$ \\
\hline
\end{tabular}

most closely to ' $[S$.] cauliformis' DSM 3657 and $F$. johnsoniae DSM 425 in the tree generated by fastDNAml (Fig. 4). The three strains also clustered together in the three most parsimonious trees generated by PAUP (not shown), however in two of these trees, '[S.] cauliformis' DSM 3657 and $F$. johnsoniae DSM 425 joined prior to ACAM $376^{\mathrm{T}}$ joining the cluster.

A comparison of available $16 \mathrm{~S}$ rRNA/rDNA sequences showed that ACAM $376^{\mathrm{T}}$ was most similar to $F$. columnare ATCC 43622 and ' $[S$.] cauliformis' DSM 3657 , at $97 \cdot 8 \%$ similarity. $F$. columnare ATCC 43622 did not cluster with ACAM $376^{\mathrm{T}}$ as Flavobacterium columnare ATCC 43622 was more closely related in $16 \mathrm{~S}$ rDNA sequence to strains of a number of other taxa (e.g. $98.7 \%$ similar to $F$. saccharophilum ATCC $49530^{\mathrm{T}}$ and $98.0 \%$ similar to $F$. pectinovorum DSM $6368^{\mathrm{T}}$ ). ACAM $376^{\mathrm{T}}$ was only distantly related $(91.7 \%)$ in $16 \mathrm{~S} \mathrm{rDNA}$ sequence to the type strain of $F$. columnare ATCC $2346^{\mathrm{T}}$. The sequence dissimilarity between $F$. columnare ATCC 43622 and $F$. columnare ATCC $2346^{\mathrm{T}}$ was $7 \cdot 7 \%$, which would suggest that ATCC 43622 has been mis-identified. ACAM $376^{\mathrm{T}}$ could not be accommodated in the same species as " $[S$. $]$ cauliformis' DSM 3657 due to its low DNA-DNA hybridization value (Table 1). The nearest type strains of validly published species to ACAM $376^{\mathrm{T}}$, were $F$. hydatis NCIMB $2215^{\mathrm{T}}$ and $F$. saccharophilum ATCC $49530^{\mathrm{T}}$ with $16 \mathrm{~S}$ rDNA sequence similarities of 97.4 and $97.3 \%$, respectively. Both of these type strains gave low values, $<20 \%$, in DNA-DNA hybridization studies (Table 1). ACAM $376^{\mathrm{T}}$ was also $97.6 \%$ related in $16 \mathrm{~S}$ rDNA sequence to the reference strain $F$. johnsoniae DSM 425, but only distantly related $(95.1 \%)$ in sequence to the type strain of $F$.johnsoniae, ATCC $17061^{\mathrm{T}}$. ACAM $376^{\mathrm{T}}$ showed low DNA-DNA hybridization to the reference strain $F$. johnsoniae DSM 425 (Table 1). On molecular evidence alone, ACAM 376 ${ }^{\mathrm{T}}$ and the closely related strain ACAM 377 should be described as a new species of the genus Flavobacterium.

In addition to the outcomes of the phylogenetic comparisons (Fig. 4.) and the DNA-DNA hybridization data (Table 1), strains ACAM 376 and ACAM 377 can be easily distinguished phenotypically from their nearest taxonomic counterparts (Table 2). On phenotypic grounds, the most similar species to the proposed species $F$. hibernum is $F$. hydatis. Of the 
major phenotypic attributes currently used to differentiate species of the genus Flavobacterium (Bernardet et al., 1996), the species differ in their colony morphology, ability to degrade CM-cellulose, pectin and chitin, and their ability to produce cytochrome oxidase (Table 2). Although the description of ' $S$.] cauliformis' is scant, unlike ACAM $376^{\mathrm{T}}$, members of the species form microcysts and do not produce acid from monosaccharides or disaccharides such as glucose or lactose (Gräf, 1962).

On the basis of the aforementioned molecular and phenotypic data, ACAM $376^{\mathrm{T}}$ and ACAM 377 can be designated as a new species of the genus Flavobacterium, for which the name Flavobacterium hibernum is proposed.

\section{Ecology of Flavobacterium hibernum}

Flavobacterium hibernum was isolated from Crooked Lake, a freshwater lake of the Vestfold Hills region of Antarctica. Like most bacteria described thus far from Antarctic continental ecosystems, it is a psychrotroph (Ellis-Evans, 1985) with an optimal temperature for growth of $26^{\circ} \mathrm{C}$. Its ability to glide on surfaces and to lyse Gram-negative cells suggests a bacteriovorous role for this species in its environment. In Crooked Lake, as in most freshwater Antarctic Lakes, the amount of particulate organic carbon $\left(227 \mu \mathrm{g} \mathrm{l}^{-1}\right.$ in Crooked Lake) greatly exceeds that of dissolved organic carbon $\left(1.5 \mu \mathrm{g}^{-1}\right.$ in Crooked Lake) (Laybourne-Parry \& Marchant, 1992). Antarctic freshwater lakes generally lack planktonic metazoa and the microbial loop is the primary route of nutrient recycling.

The ability of $F$. hibernum to favour a gelatinous colony at low temperature may be an adaptation to desiccation during freezing in the Antarctic autumn, as the ability to produce exopolysaccharides has been linked to desiccation resistance (Ophir \& Gutnick, 1994).

Although the species had a temperature optimum for growth of $26^{\circ} \mathrm{C}$ and failed to grow at temperatures over $30^{\circ} \mathrm{C}$, the optimum temperature for $\beta$ galactosidase activity of this organism was $38.6{ }^{\circ} \mathrm{C}$. Activity of $\beta$-galactosidases at temperatures well above those tolerated by the producing strain seems a common occurrence (Loveland et al., 1994). There are clearly better thermally adapted $\beta$-galactosidases already available for use in the dairy industry (Mahonev, 1985) than those produced by $F$. hibernum.

\section{Description of Flavobacterium hibernum sp. nov.}

Flavobacterium hibernum (hi.ber'num. L. adj. hibernus, $-a,-u m$ wintery/of winter).

Gram-negative rods, $0.7 \times 1.8-13 \mu \mathrm{m}$ that exhibit gliding motility on fresh, nutrient-poor medium. Colonies on media containing $0.5 \%$ lactose and $0.1 \%$ yeast extract are discrete, opaque, shiny, smooth and yellow, mucoid when grown at $25^{\circ} \mathrm{C}$ but gelatinous when grown at $4{ }^{\circ} \mathrm{C}$. Cells grown at $4{ }^{\circ} \mathrm{C}$ possess a thick capsule. Congo red is not adsorbed. The optimal temperature for growth is $26^{\circ} \mathrm{C}$. The maximum temperature for growth is $30-31{ }^{\circ} \mathrm{C}$ and the strain grows to the medium freezing point in media prepared with fresh water. The theoretical minimum temperature for growth is $-7^{\circ} \mathrm{C}$. Good growth on Trypticase soy agar. No growth on media prepared in sea water. On nutrient-poor medium, colonies spread and are flat. Cells of E. coli are lysed by members of the species. Catalase-positive, oxidase-negative and aerobic. Nitrate is reduced. Menaquinone 6 is the major $(>94 \%)$ respiratory lipoquinone. Flexirubin pigments are produced. Whole cells contain a wide range of saturated, branched, monounsaturated and 3-OH fatty acids, but are dominated by i15:0, a15:0, 15:0, i1 $5: 1 \omega 10 c, 16: 1 \omega 7 c$ and 3-OHi15:0. Acid is produced from glucose and a range of sugars including glucose, lactose, galactose, fructose and sucrose, but not raffinose, are utilized. $\beta$-Galactosidase is produced. Tween 40 and 80 are hydrolysed. No precipitate is formed on egg yolk agar. Gelatin, casein, starch, aesculin, DNA and tyrosine are degraded. CM-cellulose, agar, alginate, pectin and chitin are not degraded. $\mathrm{G}+\mathrm{C}$ content of DNA is $34 \mathrm{~mol} \%$. The type strain ATCC $51468^{\mathrm{T}}\left(=\right.$ ACAM $\left.376^{\mathrm{T}}\right)$ was isolated from an Antarctic freshwater lake.

\section{ACKNOWLEDGEMENTS}

P.D.F and S.J.D were supported by Australian Research Council Fellowships. The study was supported in part by grants from the Australian Research Council and the Antarctic Science Advisory Committee.

\section{REFERENCES}

Athalye, M., Goodfellow, M. \& Minnikin, D. E. M. (1984). Menaquinone composition of Actinomadura and related taxa. $J$ Gen Microbiol 130, 817-823.

Bernardet, J.-F., Segers, P., Vancanneyt, M., Berthe, F., Kersters, K. \& Vandamme, P. (1996). Cutting a Gordian knot: emended classification and description of the genus Flavobacterium, emended description of the family Flavobacteriaceae, and proposal of Flavobacterium hydatis nom. nov. (basonym, Cytophaga aquatilis Strohl and Tait 1978). Int J Syst Bacteriol 46, 128-148.

Bowman, J. P., Austin, J. J., Cavanagh, J. \& Sanderson, K. (1996). Novel Psychrobacter species from ornithogenic soils. Int $J$ Syst Bacteriol 46, 841-848.

Dobson, S. J., Colwell, R. R., Franzmann, P. D. \& McMeekin, T. A. (1993). Direct sequencing of the PCR-amplified 16S rRNA gene of Flavobacterium gondwanense sp. nov. $\left(\mathrm{ACAM} 44^{\mathrm{T}}=\mathrm{DSM}\right.$ $5425^{\mathrm{T}}$ ), and Flavobacterium salegens sp. nov. (ACAM $48^{\mathrm{T}}=$ DSM 5424 $4^{T}$, new species from a hypersaline Antarctic lake. Int $J$ Syst Bacteriol 43, 77-83.

Ellis-Evans, J. C. (1985). Microbial ecology in Antarctica. Biologist 32, 171-176.

Gherna, R. \& Woese, C. R. (1993). A partial phylogenetic analysis of the 'flavobacter-bacteroides' phylum: basis of taxonomic restructuring. Syst Appl Microbiol 15, 513-521. 
Gounot, A.-M. (1991). Bacterial life at low temperature; physiological aspects and biotechnological implications. A review. $J$ Appl Bacteriol 71, 386-397.

Gräf, w. (1962). Über Wassermyxobakterien. Arch $\mathrm{H}_{y} g$ Bacteriol 146, 114-125.

Hildebrand, D. C. (1971). Pectate and pectin gels for differentiation of Pseudomonas sp. and other bacterial pathogens. Phytopathology 61, 1430-1436.

Huss, V. A. R., Festl, H. \& Schleifer, K. H. (1983). Studies on the spectrophotometric determination of DNA hybridization from renaturation rates. Syst Appl Microbiol 4, 184-192.

Larsen, N., Olsen, G. J., Maidak, B. L., McCaughey, M. J., Overbeek, R., Macke, T. J., Marsh, T. L. \& Woese, C. R. (1993). The ribosomal database project. Nucleic Acid Res 21 (suppl), 3021-3023.

Laybourne-Parry, J. \& Marchant, H. (1992). The microbial plankton of freshwater lakes in the Vestfold Hills, Antarctica. Polar Biol 12, 405-410.

Loveland, J., Gutshall, K., Kasmir, J., Prema, P. \& Brenchley, J. E. (1994). Characterization of psychrotrophic microorganisms producing $\beta$-galactosidase activities. Appl Environ Microbiol 60 , $12-18$.

McCurdy, H. D., Jr (1969). Study on the taxonomy of the Myxobacterales. I. Record of Canadian isolates and survey of methods. Can J Microbiol 15, 1453-1461.

Mahoney, R. R. (1985). Modification of lactose and lactosecontaining dairy products with $\beta$-galactosidase. In Developments in Dairy Chemistry, vol 3, Lactose and Minor Constituents, pp. 69-109. Edited by P. F. Fox. London: Elsevier.

Mesbah, M., Premachandran, U. \& Whitman, W. B. (1989). Precise measurement of the $\mathrm{G}+\mathrm{C}$ content of deoxyribonucleic acid by high-performance liquid chromatography. Int $J$ Syst Bacteriol 39, 159-167.

Miller, J. H. (1972). Assay of $\beta$-galactosidase. In Experiments in Molecular Genetics, pp. 352-355. Cold Spring Harbor: Cold Springs Harbor Laboratory.

Moss, C. W., Wallace, P. L., Hollis, D. G. \& Weaver, R. E. (1988).
Cultural and chemical charaterization of CDC Groups EO-2, M-5 and M-6, Moraxella (Moraxella) species, Oligella urethralis, Actinetobacter species, and Psychrobacter immobolis. $J$ Clin Microbiol 26, 484492.

Murray, M. G. \& Thompson, W. F. (1980). Rapid isolation of high molecular weight plant DNA. Nucleic Acids Res 19, 4321-4325.

Ophir, T. \& Gutnick, D. L. (1994). A role for exopolysaccharides in the protection of microorganisms from desiccation. Appl Environ Microbiol 60, 740-745.

Ratkowsky, D. A., Lowrey, R. K., McMeekin, T. A., Stokes, A. N. \& Chandler, R. E. (1983). Model for bacterial growth throughout the entire biokinetic range. $J$ Bacteriol 154, 1222-1226.

Skerman, V. B. D. (1967). A Guide to the Identification of the Genera of Bacteria, 2nd edn. Baltimore: Williams \& Wilkins.

Skerratt, J. H., Nichols, P. D., Mancuso, C. A., James, S. R., Dobson, S. J., McMeekin, T. A. \& Burton, H. R. (1991). The phospholipid ester-linked fatty acid composition of members of the family Halomonadaceae and genus Flavobacterium: a chemotaxonomic guide. Syst Appl Microbiol 14, 8-13.

Smibert, R. M. \& Krieg, N. R. (1981). General characterisation. In Manual of Methods for General Bacteriology, pp. 409-433. Edited by P. Gerhardt and others. Washington, DC: American Society for Microbiology.

Swofford, D. L. (1990). PAUP: Phylogenetic Analysis Using Parsimony, version 3.1. Champaign, IL: Illinois Natural History Survey.

Tamaoka, J., Katayama-Fujimura, Y. \& Kuraishi, H. (1983). Analysis of bacterial menaquinone mixtures by high performance liquid chromatography. $J$ Appl Bacteriol 54, 31-36.

Vandamme, P., Bernardet, J.-F., Segers, P., Kersters, K. \& Holmes, B. (1994). New perspectives in the classification of the flavobacteria: description of Chryseobacterium gen. nov., Bergeyella gen. nov. and Empedobacter nom. rev. Int J Syst Bacteriol 44. $827-831$

West, P. A. \& Colwell, R. R. (1984). Identification and classification of the Vibrionaceae - an overview. In Vibrios in the Environment, pp. 285-363. Edited by R. R. Colwell. New York: Wiley. 